\title{
Prêmio Marta Rossetti Batista de História da Arte e da Arquitetura e Acervo Marta Rossetti Batista
}

Em outubro de 2007, foi criado pelo IEB o Prêmio Bianual Marta Rossetti Batista de História da Arte e da Arquitetura, que em sua primeira edição contemplou a monografia Quimeras da modernidade na obra de Marcelo Grassmann (Volumes I e II), de Priscilla Rossinetti Rufinoni.

O IEB passou a sediar, em de fevereiro de 2008, o acervo da professora e pesquisadora Marta Rossetti Batista, ex-diretora do Instituto. Esse acervo totaliza aproximadamente dois mil volumes de livros, algumas revistas e jornais. A documentação está contida em quarenta pastas. Livros, revistas e jornais, assim como a documentação pessoal, dizem respeito aos temas de interesse da pesquisadora, a saber: a arte popular e do Brasil colonial; a história da arquitetura e do modernismo e, finalmente, os museus - com destaque para o repertório de livros voltados para o tema da construção dos museus e a coleção de catálogos de museus brasileiros. Marta Rossetti Batista cultivou uma biblioteca sobre artistas plásticos como Rebolo, Galvez, Lasar Segall, Di Cavalcanti, Gomide, Anita Malfatti, Aleijadinho e uma mostra significativa de títulos sobre a arte colonial brasileira.

A incorporação do acervo da intelectual, que desenvolveu parte de sua trajetória intelectual junto ao acervo do IEB, já foi iniciada e a ela se seguirá a disponibilização dos livros e documentos, quando serão abertas novas perspectivas de pesquisa a partir das lições por ela deixadas.

Do acervo da professora Marta Rossetti Batista, a Revista do IEB seleciona o texto da palestra de Sergio Miceli, apresentada no Seminário Coleção Mário de Andrade: Religião e Magia. Música e Dança. Cotidiano, realizado pelo IEB em 2 de outubro de 2004, por ocasião do lançamento do catálogo de objetos da coleção Mário de Andrade'.

1 BATISTA, M. R. (Org.). Coleção Mário de Andrade: religião e magia, música e dança, cotidiano. São Paulo: Edusp; Imprensa Oficial do Estado de São Paulo, 2004. 